\title{
Integrated Gasification Combined Cycle (IGCC) as a remediation for EHR reduction
}

\author{
O. Barra ${ }^{1}$, A. Barra ${ }^{2}$, F. Buono ${ }^{2}$, A. Cuiuli ${ }^{2} \&$ P. Ionta $^{3}$ \\ ${ }^{\prime}$ University of Calabria, Physics Dept., Cosenza, Italy. \\ ${ }^{2}$ LIFE, Laboratories for Information Food and Energy, Rome, Italy. \\ ${ }^{3}$ Associazione EDENET, Post-graduate School on Energy and \\ Environment, Palazzo Cosentini, Feroleto Antico, Catanzaro, Italy.
}

\begin{abstract}
The paper is aimed to introduce the IGCC technology as a remediation for environmental impact reduction; a new model in progress, capable to simulate the basic phenomena of fluidised bed reactor in gasifier for heavy oil, coal and urban solid wastes, is presented. The importance of the paper is due to the fastly growing interest in the world for the application of IGCC to waste treatment and sustainable energy production: in fact, whereas the incineration process is today the most common technology, the much more "cleaning" potential of the gasification technology candidates the IGCC as the true EHR remediation in medium-term strategies for the waste handling and treatment, as well as for energy recovery. The main performance parameters of a $250 \mathrm{MW}_{\mathrm{e}}$ IGCC plant for heavy oil and coal gasification are evaluated.
\end{abstract}

\section{Introduction}

The IGCC Technology is, today, the most updated technology to produce electricity from hydrocarbons, whose exploitation in traditional combustion processes is not acceptable for environmental reasons (such as heavy and extraheavy oils, coal, oil refinery tars, fuels from wastes, etc.). Because of the growing shortage of "clean" hydrocarbon fuels despite of a large availability throughout the world of "dirty" hydrocarbons, it is a common opinion that IGCC Technology will become in the near future the leading solution for power production all over the world. The IGCC Tech represents today a technological frontier in the power production sector, therefore, even if all the plant 
components and systems are well known and have a consolidated work experience, the success of a new initiative is still depending on a proper BOS (Balance Of System) and on an optimised Project Management for any specific application.

\subsection{Historical background}

A set of historical experiences dated in the ' $80 \mathrm{~s}$ and in the early ' $90 \mathrm{~s}$ are commonly mentioned to introduce the IGCC subject. The most relevant of such experiences regarding Europe and America are summarized in the Table 1 hereinafter:

Table 1. The most relevant historical experiences.

\begin{tabular}{|c|c|c|c|c|c|}
\hline \multirow{2}{*}{$\begin{array}{c}\text { TECHNOLOGY OR } \\
\text { IMPLEMENTING } \\
\text { BODY }\end{array}$} & \multicolumn{2}{|c|}{ PLANT } & \multirow[t]{2}{*}{ CAPACITY } & \multirow{2}{*}{$\begin{array}{l}\text { EXPERIENCE OR } \\
\text { START- UP (YEAR) }\end{array}$} & \multirow[t]{2}{*}{ REMARKS } \\
\hline & Name/Country & Type (*) & & & \\
\hline TEXACO & $\begin{array}{l}\text { Cool } \\
\text { Water }\end{array}$ & CTCC & $\begin{array}{l}1000 \mathrm{t} / \mathrm{d} \\
100 \mathrm{MWe}\end{array}$ & $\begin{array}{c}10^{6} \text { tons of gasified coal } 3.10^{9} \\
\text { of Kwhe produced }\end{array}$ & $\begin{array}{l}\text { Several types of } \\
\text { coal tested }\end{array}$ \\
\hline SHELL & $\begin{array}{l}\text { SCGP-1 } \\
\text { Houston, Texas }\end{array}$ & CSGP & $250 \mathrm{t} / \mathrm{d}$ & $>12000$ working hours & $\begin{array}{l}\text { Several types of } \\
\text { coal tested }\end{array}$ \\
\hline$\overline{B G L}$ & Westfield & $\overline{\mathrm{CBGP}}$ & $500 \mathrm{t} / \mathrm{d}$ & $\begin{array}{l}500 \text { tons of UK coal }+15000 \\
\text { tons of USA coal }\end{array}$ & $\begin{array}{l}\text { Tests for CEE } \\
\text { and EPRI }\end{array}$ \\
\hline$\overline{\mathrm{DOW}}$ & $\begin{array}{l}\text { Cool } \\
\text { Water }\end{array}$ & CDGP & $1200 \mathrm{t} / \mathrm{d}$ & $10^{6}$ tons of gasified coal & $\begin{array}{l}\text { Several types of } \\
\text { coal tested }\end{array}$ \\
\hline HTW & Berrenrath & $\overline{C W G P}$ & $700 \mathrm{t} / \mathrm{d}$ & $\begin{array}{l}>20000 \text { working hours with } \\
\text { german coal }\end{array}$ & Fluidized bed \\
\hline $\begin{array}{l}\text { U-GAS } \\
\text { KRWestinghouse } \\
\text { PRENFLO }\end{array}$ & Several sites & $\begin{array}{l}\text { CUGP } \\
\text { CKGP } \\
\text { CPGP }\end{array}$ & $25 \div 50 \mathrm{t} / \mathrm{d}$ & Pilot Plant & - \\
\hline QUANTUM & $\begin{array}{l}\text { USA } \\
\text { La Porte }\end{array}$ & $\begin{array}{l}\text { Oil Gasif. } \\
\text { Process }\end{array}$ & $\begin{array}{l}3000 \text { t/d } \\
\text { oxigen plant } \\
86 \text { bar }\end{array}$ & $19 \overline{82}$ & $\begin{array}{l}\text { Commissioned } \\
\text { in } 1979\end{array}$ \\
\hline STAR Ent. & $\begin{array}{l}\text { USA } \\
\text { Convent, LA }\end{array}$ & $\begin{array}{l}\text { Oil Gasif. } \\
\text { Process }\end{array}$ & $\begin{array}{l}1500 \mathrm{t} / \mathrm{d} \\
\text { oxigen plant } \\
86 \mathrm{bar}\end{array}$ & 1986 & $\begin{array}{l}\text { Commissioned } \\
\text { in } 1982\end{array}$ \\
\hline DESTEC & $\begin{array}{l}\text { USA } \\
\text { Plaquemine, LA }\end{array}$ & $\begin{array}{l}\text { Coal Gasif. } \\
\text { Process }\end{array}$ & $\begin{array}{l}1500 \mathrm{t} / \mathrm{d} \\
\text { oxigen plant } \\
45 \text { bar }\end{array}$ & 1993 & $\begin{array}{l}\text { Commissioned } \\
\text { in } 1987\end{array}$ \\
\hline $\begin{array}{l}\text { SOUTHERN } \\
\text { CALIFORNIA } \\
\text { EDISION/DOE }\end{array}$ & USA & CTCC & $\begin{array}{l}900 \mathrm{Vd} \\
90 \mathrm{MWe}\end{array}$ & 1993 & $\begin{array}{l}\text { Revamping of } \\
\text { the Cool Water } \\
\text { Plant }\end{array}$ \\
\hline
\end{tabular}

(*) $\mathrm{C}=$ Coal, $\mathrm{T}=$ Texaco, $\mathrm{S}=$ Shell, $\mathrm{B}=\mathrm{BGL}, \mathrm{D}=\mathrm{DOW}, \mathrm{W}=\mathrm{HTW}, \mathrm{U}=\mathrm{U}-\mathrm{GAS}, \mathrm{K}=\mathrm{KRW}, \mathrm{P}=\mathrm{PRENFLO}, \mathrm{I}=$ Integrated, $\mathrm{G}=$ Gasification, $\mathrm{CC}=$ Combined Cycle, $\mathrm{GP}=$ Gasification Process Only, $\mathrm{H}=$ Heavy Oil or Orimulsion, $\mathrm{T}=\mathrm{Tar}$ (Refinery Residue)

On the basis of these early experiences, several large size plants have been implemented and are today already working or are under construction.

Among the former, the European experience in the famous $500 \mathrm{MW}$ DEMKOLEC plant in The Netherlands must be emphasized. This plant has been operating since the end of 1994.

Among the latter, Kobra Plant (320 $\mathrm{MW}_{\mathrm{e}}$ ) in Germany, Puertollano Plant (300 $\mathrm{MW}_{\mathrm{e}}$ ) in Spain, Lubeck $\left(320 \mathrm{MW}_{\mathrm{e}}\right)$ and Duisburg $\left(170 \mathrm{MW}_{\mathrm{e}}\right.$ ) plants in Germany are well known together with Italian activities, such as the API plant in Falconara (Ancona), fed by refinery tar, the ISAB plant in Priolo (Sicily), the possible AGIP plants form heavy oils and/or tar, and the possible Sardinian plant form Sulcis coal. 


\subsection{The IGCC plant: technology and environmental preservation}

Figure 1 shows a typical general scheme of an IGCC Plant.

The three main blocks of the diagram are functionally integrated. The air separation plant A1 receives about two thirds of its air from its compressor and one third from the gas turbine, and it is calibrated at the same pressure of the turbine. Part of the nitrogen separated from the air, compressed and heated, is used to dilute the cleaned syngas sent to the turbogas; the preheated oxygen is sent to the gasifier A2 obtaining a hot synthesis oil which, first of all, is cooled in the "syncooler" A3, producing steam (HRSG), together with the waste heat recovered from the gasifier walls, and then sent to the A5 unit to remove all its sulfured contaminants. The latter, sent to a classical Claus-Scot (A6) unit, produce commercial sulfur placed into the market. The cleaned syngas and the steam produced in the syncooler enter a classical combined cycle gas turbinesteam turbine (sections B and C), sending to the latter also the steam produced by the turbogas exhaust gas, having first taken away the steam quantity necessary for its own uses in the gasification process.

In this way it is possible to obtain high energy efficiency, greater than $45 \%$ for electricity production, and for an environmental protection better than any other use of fossil fuels.

In fact, as far as the nitrogen oxides are concerned, the use of "dry" low $\mathrm{NO}_{\mathrm{x}}$ burners possible in gas turbine plants, together with the mentioned dilution of the syngas with nitrogen, leads to $\mathrm{NO}_{\mathrm{x}}$ emission values in the range $0.3-0.5 \mathrm{~g} / \mathrm{kWh}$ produced. As far as carbon dioxide is concerned, the high energy efficiency of the whole process implies a $\mathrm{CO}_{2}$ generation for each $\mathrm{kWh}$ produced at least $15 \%$ lower than any other thermoelectric power station. The recovery and the recycle of the soot CR in A4 and the ashes inertization (which can be placed to the market as a substitute of the sand up to $35 \%$ in weight in the concrete) allows that the particles emission is one or more orders of magnitude lower than the traditional values. The presence of the gas turbine, furthermore without the use of steam for the $\mathrm{NO}_{\mathrm{x}}$ decay, finally allows a water consumption of the whole system less than half of a traditional boiler-steam turbine plant. 


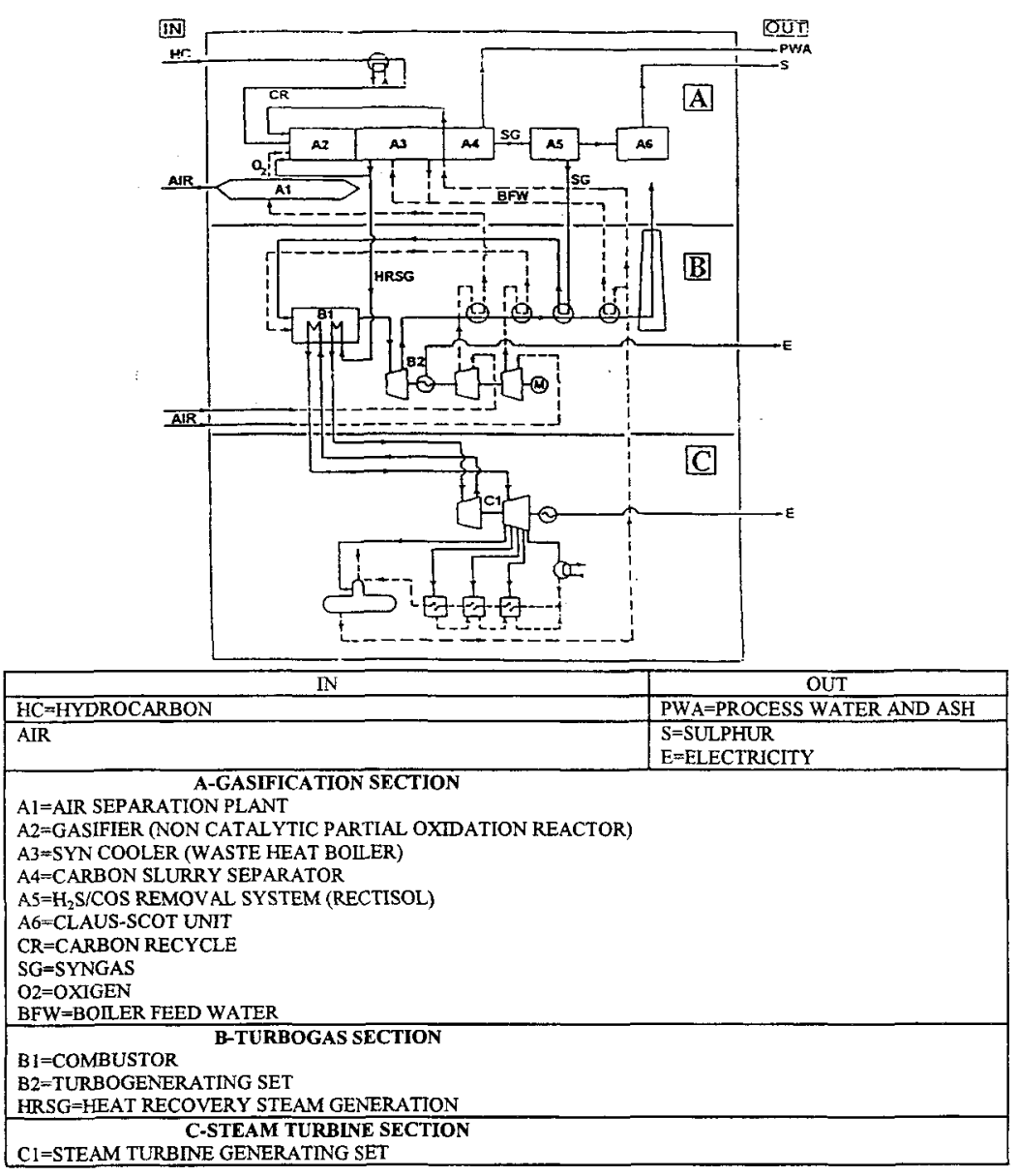

Figure 1: Typical general scheme of an IGCC Plant.

\section{IGCC scientific fundamentals}

The non-catalytic hydrocarbon partial oxidation reaction which is carried out at elevated temperatures $\left(1100-1500^{\circ} \mathrm{C}\right)$ may be represented by the following overall reaction:

$\mathrm{C}_{\mathrm{n}} \mathrm{H}_{\mathrm{m}} \mathrm{S}_{\mathrm{r}}+\mathrm{n} / 2 \cdot \mathrm{O}_{2} \longrightarrow \mathrm{n} \cdot \mathrm{CO}+(\mathrm{m} / 2-\mathrm{r}) \cdot \mathrm{H}_{2}+\mathrm{r} \cdot \mathrm{H}_{2} \mathrm{~S}$

The reaction is higly exothermic and becomes increasingly so with higher molecular weight hydrocarbons and polynuclear hydrocarbons, owing to the greater energy of formation of $\mathrm{CO}$ from $\mathrm{C}-\mathrm{C}$ bonds compared with that from $\mathrm{C}$ $\mathrm{H}$ bonds. If the available oxygen is less than the quantity required from eqn (1) 
for the amount of treated hydrocarbons (partial oxidation), and if st available, $\mathrm{CO}$ and the non-oxidized percentage of hydrocarbons, exp of the energy available in eqn (1), give the following further reactions CO shift-reaction

(still slightly exothermic)

$\mathrm{CO}+\mathrm{H}_{2} \mathrm{O} \longrightarrow \mathrm{CO}_{2}+\mathrm{H}_{2}$

\section{reforming}

(strongly endothermic)

$\mathrm{C}_{\mathrm{n}} \mathrm{H}_{\mathrm{m}} \mathrm{S}_{\mathrm{r}}+\mathrm{r} . \mathrm{CO} \longrightarrow \mathrm{C}_{\mathrm{n}} \mathrm{H}_{\mathrm{m}}+$ r. COS

$\mathrm{C}_{\mathrm{n}} \mathrm{H}_{\mathrm{m}}+$ n. $\mathrm{H}_{2} \mathrm{O} \longrightarrow \mathrm{n} \cdot \mathrm{CO}+(\mathrm{m} / 2+\mathrm{n}) \cdot \mathrm{H}_{2}$

$\mathrm{C}_{\mathrm{n}} \mathrm{H}_{\mathrm{m}}+\mathrm{n} \cdot \mathrm{CO}_{2} \longrightarrow 2 \mathrm{n} \cdot \mathrm{CO}+\mathrm{m} / 2 \cdot \mathrm{H}_{2}$

Carbon formation

$\mathrm{C}_{\mathrm{n}} \mathrm{H}_{\mathrm{m}} \longrightarrow \mathrm{n} \cdot \mathrm{C}+\mathrm{m} / 2 \cdot \mathrm{H}_{2} \quad$ (cracking)

$2 . \mathrm{CO} \longrightarrow \mathrm{CO}_{2}+\mathrm{C} \quad$ (Boudouard)

\section{Sulfur shift-reaction}

$\mathrm{H}_{2}+\mathrm{COS} \longrightarrow \mathrm{H}_{2} \mathrm{~S}+\mathrm{CO}$

Methane partial formation

$\mathrm{CO}+3 . \mathrm{H}_{2} \longrightarrow \mathrm{CH}_{4}+\mathrm{H}_{2} \mathrm{O}$

The equilibrium for shift-reaction, eqn (2), determines the proportio that is converted to $\mathrm{CO}_{2}$ and hence the $\mathrm{H}_{2}: \mathrm{CO}$ final ratio.

The equilibrium for shift-reaction, eqn (8), determines the final ral hydrogen sulfide $\left(\mathrm{H}_{2} \mathrm{~S}\right)$ and carbonyl sulfide (COS).

The $C$ production (Carbon Slurry) in eqns (6) and (7) is mainly det the ratio between input oxygen and input hydrocarbon, whereas $t$ production, eqn (9), depends on the oxygen/hydrocarbon and steam $/ \mathrm{h}$ ratios and decreases when the process temperature increases. described process takes place only if the following thermodynamic are satisfied for the input raw material amounts (hydrocarbons, oxyge $>$ oxygen (measured in $\mathrm{Nm}^{3}$ ) $\leq$ hydrocarbons (measured in $\mathrm{kg}$ ) $>$ steam (measured in $\mathrm{kg}$ ) $\leq$ oxygen (measured in $\mathrm{Nm}^{3}$ )

With these boundary limits and taking into account that the oxyg coming form an air separation unit) will carry also some nitroger traces, it is clear that the process final products will be:

- a small amount of solid carbon slurry (given from eqns (6) : usually recycled to the cycle itself)

- a synthesis gas (just named SYNGAS) at a temperature $\mathrm{i}$ $1200-1400{ }^{\circ} \mathrm{C}$, with an Heating Value in the range $\mathrm{kCal} / \mathrm{Nm}^{3}$, with the following chemical composition (dry prc

$$
\begin{array}{ll}
\mathrm{CO}_{2} & 30 \div 60 \% \\
\mathrm{H}_{2} & 60 \div 30 \% \\
\mathrm{CO}_{2} & \\
\mathrm{CH}_{4} & \\
\mathrm{~N}_{2}+\mathrm{Ar} & \\
\mathrm{H}_{2} \mathrm{~S}+\mathrm{COS} &
\end{array}
$$


The performance of the gasifier (the partial oxidation reactor) is physically characterized by two parameters, "Cold Gas Efficiency"- CGE - and "Specific Oxygen Consumption"- SOC -, defined as follows:

$$
\begin{aligned}
\text { CGE } & =\frac{\text { Higher Heating Value of }\left(\mathrm{CO}+\mathrm{H}_{2}\right) \text { produced }}{\text { Higher Heating Value of Feedstock Consumed }} \\
\mathrm{SOC} & =\frac{\mathrm{Nm}^{3} \text { of pure } \mathrm{O}_{2} \text { used }}{\text { Thousands } \mathrm{Nm}^{3} \text { of }\left(\mathrm{CO}+\mathrm{H}_{2}\right) \text { produced }}
\end{aligned}
$$

CGE is not a thermodynamic efficiency but merely a statement of yield and lies in the range $82 \div 85 \%$ for most liquid and gaseous feedstocks. When the heat recovered (in the steam produced) is included, the overall efficiency is usually 92 to $94 \%$. Figure 2 is a graphical representation of the typical dependence of CGE on SOC for a vacuum residue feedstock. The theoretical curve shows the performance when carbon (soot) formation is zero and methane formation corresponds to the thermodynamic equilibrium. The CGE's shown include an allowance for normal heat losses. At the right of the maxima for CGE, the efficiency decreases because of a more complete combustion, and toward the left the fall off in efficiency is due to increased methane production (caused by the drop in reactor temperatures in this direction). Curves for the real situation where soot formation does occur are also shown in Figure 2, for zero, $80 \%$ and $100 \%$ levels of soot recycle. The levels of unconverted carbon are indicated by numbers at the data points. Again, towards the right of the maxima, in the fuellean region, a more complete combustion leads to a decrease in CGE with increased SOC. To the left (in the fuel-rich region) CGE decreases because of increasing soot and methane formation. At very low feed oxygen/oil ratios, the SOC increases again, as this is the ratio of oxygen to product rather than to feed. Since both oxygen and feedstock consumptions represent key raw materials costs, the optimum point is usually slightly displaced from the peak CGE. When soot is not recycled, the optimum oxygen/feedstock ratio is on the fuel-rich side of the maxima. With soot recycle to extinction, the CGE obtainable is higher than without recycle but in this case the optimum oxygen/feedstock ratio shifts to the fuel-lean side of the maxima, because of the capital and operating costs for recycling the carbon. The other parameters which determine partial oxidation reactor performance are the steam/oil ratio and the operating pressure. Increasing the steam/oil ratio leads to enhanced $\mathrm{H}_{2}: \mathrm{CO}$ ratios but leads to a higher $\mathrm{SOC}$ and a lower CGE. Increased pressures result in greater methane production and this implies a lower CGE for any given SOC. Usually this effect is small compared with the other advantages: greater output per gasifier, lower compression power (when syngas is required at higher pressures), more efficient steam generation, and reduced costs for separation of acid gas. 


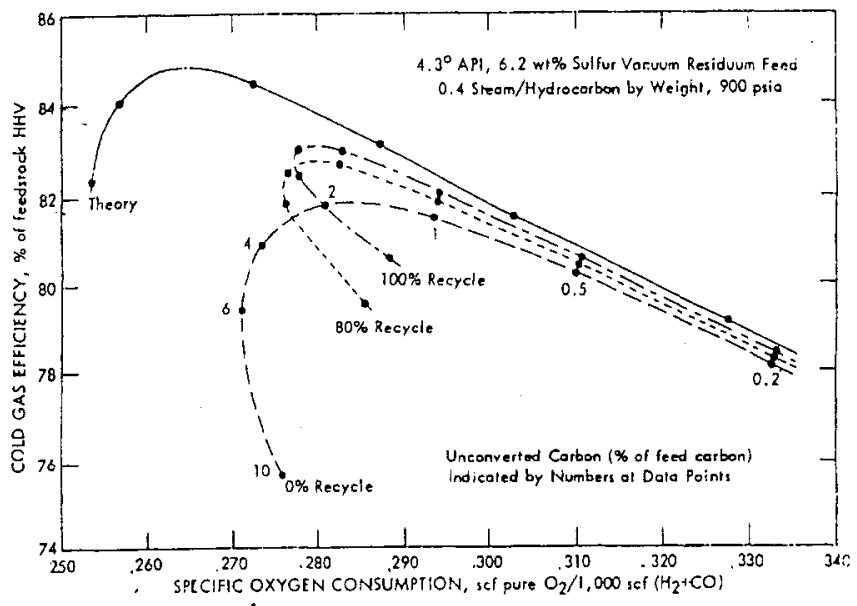

Figure 2: Partial Oxidation Reactor Performance.

Effects of Feed Oxigen/Oil Ratio and Soot Recycle.

\section{A new model in progress to simulate IGCC performances}

Are not so many the models that during the last decades made possible the prediction of the fluidised-bed reactors' performance. In 1968 an important contribution came from Kunii and Levenspiel' s theory. In their study, the fluidised-bed reactor consists of three phases: bubble, cloud and emulsion phase. According to their model there is gas interchange between bubble and cloud and between cloud and emulsion. The average size of particles has an important part in this model; in fact there are three different equations' sets (for small particles $d_{p}<100 \mu \mathrm{m}$; for medium size particles $40 \mu \mathrm{m}<d_{p}<500 \mu \mathrm{m}$; for large particles $d_{p}>1$ $\mathrm{mm}$ ) to calculate the degree of conversion in the bed of particles fluidised by a reacting gas $\mathrm{A}$. The analysis of this model showed its discontinuity. In the reality the transition from a fluid dynamic regime to another doesn't happen by fits and starts but by a gradual change of some physical parameters. And for this reason we changed this model in such a way as to remove the discontinuities and to apply it in any case. In this new model the fluidised-bed reactor consists again of three phases (bubble phase, cloud phase and emulsion phase) and the material balance equations are: 


$$
\begin{aligned}
\frac{d c_{A b}}{d z}=-\frac{c_{A b}}{V_{g b}} \frac{d V_{g b}}{d z}-\frac{\gamma_{b}}{u_{b}+\beta u_{m f}} k_{r} c_{A b}-\frac{K_{b c}}{u_{b}+\beta u_{m f}}\left(c_{A b}-c_{A c}\right)+ \\
\quad-\frac{K_{b e}}{u_{b}+\beta u_{m f}}\left(c_{A b}-c_{A e}\right) \\
\frac{d c_{A c}}{d z}=-\frac{c_{A c}}{V_{g c}} \frac{d V_{g c}}{d z}-\frac{1}{\left(f_{c}+f_{w}\right)} \frac{\gamma_{c}}{u_{m f}} k_{r} c_{A c}-\frac{1}{\left(f_{c}+f_{w}\right)} \frac{K_{c e}}{u_{m f}}\left(c_{A c}-c_{A c}\right)+ \\
+\frac{1}{\left(f_{c}+f_{w}\right)} \frac{K_{b c}}{u_{m f}}\left(c_{A b}-c_{A c}\right) \\
\frac{d c_{A e}}{d z}=-\frac{c_{A e}}{V_{g e}} \frac{d V_{g e}}{d z}-\frac{\delta}{\left[1-\delta-\left(f_{c}+f_{w}\right) \delta\right]} \frac{\gamma_{e}}{u_{m f}} k_{r} c_{A e}+ \\
+\frac{\delta}{\left[1-\delta-\left(f_{c}+f_{w}\right) \delta\right]} \frac{K_{c e}}{u_{m f}}\left(c_{A c}-c_{A e}\right)+ \\
+\frac{\delta}{\left[1-\delta-\left(f_{c}+f_{w}\right) \delta\right]} \frac{K_{b e}}{u_{m f}}\left(c_{A b}-c_{A e}\right)
\end{aligned}
$$

where $c_{A b}, c_{A c}, c_{A e}$ are the concentrations of $A\left(m o l / \mathrm{m}^{3}\right.$ gas) respectively in bubble, cloud and emulsion phase; $V_{g b}, V_{g c}, V_{g e}$ are the gas volumes ( $m^{3}$ gas) in the three phases; $\gamma_{b}, \gamma_{c}, \gamma_{e}$ are the volume of solids dispersed respectively in the bubbles, in the clouds and in the emulsion phase per bubble volume; $\mathrm{K}_{\mathrm{bc}}, \mathrm{K}_{\mathrm{ce}}, \mathrm{K}_{\mathrm{bc}}$ are the gas interchange coefficients $\left(\mathrm{s}^{-1}\right)$ between bubble and cloud phase, cloud and emulsion phase and bubble and emulsion phase; $\delta$ is the bed fraction consisting of bubbles; $f_{c}$ and $f_{w}$ are respectively the volume fraction of cloud per bubble volume and the volume fraction of wake region per bubble volume; $u_{b}$ is the velocity of a bubble rising through the bed $(\mathrm{m} / \mathrm{s}) ; \mathrm{u}_{\mathrm{mf}}$ is the superficial gas velocity at minimum fluidising conditions $(\mathrm{m} / \mathrm{s}) ; z$ is the distance above the distributor $(\mathrm{m})$ and finally $\mathrm{K}_{\mathrm{r}}$ is the rate constant.

When $u b /(u m f / \varepsilon m f)>1$, that is when in the fluidised-bed reactor there are small particles or medium size particles, the rising velocity of bubbles is greater than the velocity of fluidising fluid in the emulsion phase and this gives rise to gas circulation round the bubbles. In fact the fluidising fluid leaves the roof of the bubble and, after making a circuit within the particles, returns again to the bubble; the cloud is as far as any fluid within the bubble can travel.

In this case in the fluidised-bed reactor there are all three phases and we use all three material balance equations but without gas interchange between bubble and emulsion. On the contrary when $u b /(u m f / \varepsilon m f)<1$, that is when in the fluidisedbed reactor there are large particles, the velocity of fluidising fluid in the emulsion phase is greater than the rising velocity of bubbles. The fluid goes through the bubbles because it is more easy with respect to dense phase.

In this case in the fluidised-bed reactors there are only the bubble phase and the emulsion phase. And so we use the eqns (10) and (12) without gas interchange between bubble and cloud and between cloud and emulsion.

We solve the three ordinary differential equations (10), (11) and (12) with the fourth-order Runge-Kutta method. 


\section{IGCC main design parameters calculation}

The basic process equations introduced above can be applied to any kind of hydrocarbon: natural gas (for example in order to change its composition for process reasons), liquid (with any level of density/viscosity), solid (coals).

The results are presented in four synoptic Tables, in comparison with the results of analogous calculations carried out for other hydrocarbons already exploited in similar plants. In Table 2 the composition of the produced syngas is presented as a function of the input raw material flows, for ten different input hydrocarbons. The composition of the coal considered in Table 2 is detailed in Table 3, whereas the assumed composition of the Orinoco Oil (and subsequent Orimulsion) as well as the considered composition of the Varadero Oil (Cuba) are referred in Table 4; composition of natural gas and refinery products and by-products of Table A are supposed not to need further specifications. Finally Table 5, starting from the information included in Tables $2,3,4$, with specific reference to the IGCC plant outline introduced in Sec. 1, shows the whole energy and materials cycles (flows and balances) evaluated in for a $250 \mathrm{MW}$ (net) IGCC Power Plant fed by three interesting hydrocarbon fuels:

- ORIMULSION;

- COAL;

- VARADERO OIL.

The input additional fuel mentioned in Table 5 (assumed as "natural gas") is the fuel necessary for the Sulfur removal subsystem, and, in the coal case only, for the hydrocarbon pre-treatment and drying too. Furthermore, the indicated input additional electricity represents the IGCC plant self-consumption, excluding the electricity consumed in the Air Separation Plant for the Oxygen production, which is emphasized in a separate way in the "Oxygen" row. All the calculations have been made for a plant size of $250 \mathrm{MW}_{\mathrm{e}}$ (net power) which is the most diffused commercial size.

Table 2: Composition of the produced syngas.

\begin{tabular}{|c|c|c|c|c|c|c|c|c|c|c|}
\hline \multirow[b]{2}{*}{ HIDROCARBON } & \multirow{2}{*}{ NATURAL GAS } & \multicolumn{6}{|c|}{ REFINERY PRODUCTS BY-PRODLCTS } & \multirow{2}{*}{$\begin{array}{l}\text { COAL } \\
\text { EL CERREJION }\end{array}$} & \multirow[b]{2}{*}{$\begin{array}{l}8^{\circ} \text { API } \\
\text { ORIMULSION }\end{array}$} & \multirow[b]{2}{*}{$\begin{array}{l}9.7^{\circ} \text { API OIL } \\
\text { (VARADERO) }\end{array}$} \\
\hline & & $\begin{array}{l}\text { 64.API } \\
\text { NAFTA }\end{array}$ & $\begin{array}{l}9.66^{\circ A P I} \\
\text { FUEL OIL }\end{array}$ & $\begin{array}{l}6^{\circ} A P I \\
\text { TAR }\end{array}$ & $\begin{array}{l}\text { WaA } \\
\text { TAPI }\end{array}$ & $\begin{array}{l}\text { "BARREL" } \\
\text { SOTTOM" }\end{array}$ & $\begin{array}{l}0^{\circ} \text { API } \\
\text { ASFALTO }\end{array}$ & & & \\
\hline \multicolumn{11}{|c|}{ RAW MATERIALS INPUT AMOUNTS FOR THE PRODUCTION OF $1 \mathrm{WWOM}$ OF DRY SYNGAS } \\
\hline $\begin{array}{l}\text { HYDROCARBON } \\
\text { (KG) }\end{array}$ & 276,8 & 313.6 & 329.8 & 341.5 & 346.1 & 36.3 .8 & 357.6 & 399.7 & $\$ 60$ & 347.5 \\
\hline $\begin{array}{l}\text { STEAM } \\
\text { (KG) }\end{array}$ & - & 78.3 & 186.9 & 1563 & 173.1 & 148.1 & 1820 & 32.3 & - & 142.5 \\
\hline $\begin{array}{c}\text { OXYGEN } \\
\text { (NM) }\end{array}$ & 2480 & 29.0 & 241.0 & 253.9 & 245.0 & 2880 & 268.0 & 323.7 & 366.7 & 354.5 \\
\hline \multicolumn{11}{|c|}{ COMPOSITLON OF THE PRODUCED SYNGAS $(\%)$} \\
\hline$\infty$ & 35.e & 453 & 47.5 & 486 & 48 & 50.9 & 493 & 62.50 & 41.50 & $\$ 6.76$ \\
\hline $\mathbf{u}_{\mathbf{z}}$ & 61.1 & 54.2 & 45.8 & 44.2 & 44.2 & 43.3 & $\$ 21$ & 30.30 & 45.00 & 4540 \\
\hline $\mathrm{CO}_{\mathbf{s}}$ & 2.6 & 2.7 & 5.7 & 5.7 & 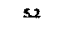 & s. & 6.5 & 1.63 & 10.70 & 5.10 \\
\hline $\mathrm{CH}_{4}$ & 0,3 & 0.7 & 0.5 & :L, 3 & 1166 & 0.3 & 0.4 & 0.02 & 0.15 & (1.,4) \\
\hline $\mathrm{N}_{1}+\mathrm{Ar}$ & t.o & A.1 & 0.2 & 8.3 & 0.2 & 0.1 & 0.4 & 5.20 & 1.00 & 0.40 \\
\hline $\mathrm{H}_{2} \mathrm{~S}+\mathrm{COS}$ & . & . & D.3 & $n .9$ & 1.5 & 0.4 & 1.3 & 0.35 & 0.85 & 1.94 \\
\hline
\end{tabular}

Source: TEXACO

Source: SHELL 
Table 3. Composition of the coal.

\begin{tabular}{|c|c|}
\hline ELEMENT & \% WEIGHT \\
\hline C & 73.4 \\
H & 4.8 \\
N & 1.8 \\
S & 1.0 \\
Cl & $(0.04)$ \\
O & 10.1 \\
ASH & 8.9 \\
\hline
\end{tabular}

Table 4. Composition of the Orinoco Oil, Orimulsion and Varadero Oil.

\begin{tabular}{|c|c|c|c|c|}
\hline PARAMETER & UNITS & $\begin{array}{l}\text { ORINOCO } \\
\text { OIL }\end{array}$ & $\begin{array}{c}\text { ORI- } \\
\text { MULSION }\end{array}$ & $\begin{array}{l}\text { VARADERO } \\
\text { OIL }\end{array}$ \\
\hline OlL & $\% w$ & 100 & 71 & 98 \\
\hline WATER & $\% \mathrm{~W}$ & $<1$ & 29 & 2 \\
\hline GASOLL & $\% \mathrm{w}$ & - & - & - \\
\hline D PARTICTE & $\mu \mathbf{m}$ & - & 17 & - \\
\hline $\begin{array}{l}\text { K. VISCOSTYY } \\
\text { (SOOC) }\end{array}$ & cSt & - & - & 2563 \\
\hline $\begin{array}{l}\text { D. VISCOSTTY } \\
(1003)\end{array}$ & & & & \\
\hline$-200 \mathrm{C}$ & mPEx & $8.10^{5}$ & 1000 & \\
\hline$-50^{\circ} \mathrm{C}$ & mP2s & $3.10^{4}$ & 500 & \\
\hline $\begin{array}{l}\text { DENSITY } \\
\text { HHV }\end{array}$ & $\begin{array}{l}{ }^{\circ A P I} \\
\text { rCalkg }\end{array}$ & $\stackrel{8}{900}$ & $\overline{7000}$ & $\begin{array}{c}9.7 \\
9600\end{array}$ \\
\hline & & & & \\
\hline \multirow{2}{*}{\multicolumn{5}{|c|}{$\frac{\text { CHEMICAL }}{\text { ANALYSIS }}$}} \\
\hline & & & & \\
\hline$c$ & $\times w$ & 84.5 & 69 & 79.91 \\
\hline B & $\% w$ & 10.4 & 7.3 & 10.49 \\
\hline $\mathrm{s}$ & $\% w$ & 3.5 & 2.5 & 8.27 \\
\hline $\mathrm{N}$ & $\% w$ & 0.7 & 0.4 & 0.37 \\
\hline 0 & $\% w$ & 0.8 & 0.5 & 0.88 \\
\hline ASH & $\% w$ & a.1 & a.1 & 0.08 \\
\hline v & min & 450 & 319 & 142 \\
\hline $\mathrm{Mi}$ & ppom & 95 & 68 & 53 \\
\hline$F_{e}$ & Ppin & 15 & 11 & - \\
\hline $\mathrm{Na}$ & $\mathrm{ppm}$ & 60 & 43 & 91 \\
\hline
\end{tabular}

Table 5. Energy and materials cycles for a 250 MW IGCC Power Plant.

\begin{tabular}{|c|c|c|c|c|c|c|}
\hline & \multicolumn{2}{|c|}{ ORIMULSION } & \multicolumn{2}{|c|}{ COAL } & \multicolumn{2}{|c|}{ VARADERO OIL } \\
\hline & Mass & Energy & Mass & Energy & Mass & Energy \\
\hline $\begin{array}{l}\text { LNPUT: } \\
\text { Oil } \\
\text { Coal (EI Cerrejon-Type) } \\
\text { Qxygen } \\
\text { Stean (from process) } \\
\text { Additional Fuel (NG) } \\
\text { Additional Electricity }\end{array}$ & \multirow[t]{2}{*}{$\begin{array}{l}75 \mathrm{t} / \mathrm{h} \\
- \\
55 \mathrm{t} / \mathrm{h} \\
- \\
208 \mathrm{Nmc/h} \\
-\end{array}$} & $\begin{array}{l}560 \mathrm{MWth} \\
- \\
38 \mathrm{MWe} \\
- \\
2 \mathrm{MWth} \\
12 \mathrm{MWe}\end{array}$ & \multirow[t]{2}{*}{$\begin{array}{l}71 \mathrm{th} \\
50 \mathrm{t} / \mathrm{h} \\
5 \mathrm{t} / \mathrm{h} \\
625 \mathrm{Nmc} / \mathrm{h} \\
-\end{array}$} & $\begin{array}{l}597 \text { MWth } \\
35 \text { MWe } \\
3 \text { MWth } \\
6 \text { MWth } \\
8 \text { MWe }\end{array}$ & \multirow[t]{2}{*}{$\begin{array}{l}61.7 \mathrm{t} / \mathrm{h} \\
5 \\
58.4 \mathrm{th} \\
45 \mathrm{t} / \mathrm{h} \\
- \\
-\end{array}$} & $\begin{array}{l}668 \mathrm{MWth} \\
26 \mathrm{MWe} \\
41 \mathrm{MWth} \\
9 \\
9 \mathrm{MWe}\end{array}$ \\
\hline TOTAL & & 562 MWth & & 606 MWth & & $709 \mathrm{MWth}$ \\
\hline $\begin{array}{l}\text { PROCESS: } \\
\text { Syngas Produced } \\
\text { Steam trom Syncooler } \\
\text { Sulphpr Removal } \\
\text { Gas Turbine Size } \\
\text { HRSG } \\
\text { Total Steam Avaitability } \\
\text { (HRSG + Syncooler) } \\
\text { Steam Turbine Size }\end{array}$ & $\begin{array}{c}140000 \mathrm{Narch} \\
130 \mathrm{t} / \mathrm{h} \\
99.4 \% \\
- \\
307 \mathrm{t} / \mathrm{h} \\
437 \mathrm{t} / \mathrm{h} \\
-\end{array}$ & $\begin{array}{l}420 \text { MWth } \\
112 \text { MWth } \\
- \\
125 \text { MWe } \\
280 \text { MWth } \\
392 \text { MWth } \\
175 \text { MWe }\end{array}$ & $\begin{array}{l}165000 \mathrm{Nmch} \\
105 \mathrm{th} \\
99.4 \% \\
- \\
235 \mathrm{th} \\
340 \mathrm{th}\end{array}$ & $\begin{array}{l}516 \text { MWth } \\
88 \text { MWth } \\
\text { 171 MWe } \\
220 \text { MWth } \\
308 \text { MWth } \\
122 \text { MWe }\end{array}$ & $\begin{array}{l}176300 \mathrm{Nmc} / \mathrm{h} \\
135.4 \mathrm{t} / \mathrm{h} \\
99.4 \% \\
- \\
347 \mathrm{t} / \mathrm{h} \\
370 \mathrm{t} / \mathrm{h} \\
\end{array}$ & $\begin{array}{l}534 \text { MWth } \\
103 \text { MWth } \\
- \\
170 \text { MWe } \\
332 \text { MWth } \\
354 \text { MWth } \\
116 \text { MWe }\end{array}$ \\
\hline $\begin{array}{l}\text { NET OUTPUT: } \\
\text { Electricity } \\
\text { Sulphar } \\
\text { Efficieacy }\end{array}$ & $3.4 \mathrm{thh}$ & $\begin{array}{l}250 \mathrm{MWe} \\
- \\
44 \%\end{array}$ & $\begin{array}{l}1.4 \mathrm{th} \\
-\end{array}$ & $\begin{array}{l}250 \mathrm{MWe} \\
- \\
42 \%\end{array}$ & $1.6 \mathrm{th}$ & $\begin{array}{l}285 \mathrm{MWe} \\
43 \%\end{array}$ \\
\hline
\end{tabular}

\section{Conclusions}

The results shown in Tables 2,4,5 constitute a powerful set of "golden rules" to outline a preliminary mass-scale design of IGCC plants in order to carry out technical-economical feasibility studies before deciding to implement plant detailed design and project development. This procedure is on-going in an important cooperation between the Canadian SHERRIT Int. Group and LIFE Group aimed to define 250 MWe IGCC modules to be implemented in Cuba (for the Varadero Crude) as well as in other applications in the world (for waste treatment). 